IRA-International Journal of Management \& Social Sciences

ISSN 2455-2267; Vol.05, Issue 02 (2016)

Pg. no. 215-226

Institute of Research Advances

http://research-advances.org/index.php/RAJMSS

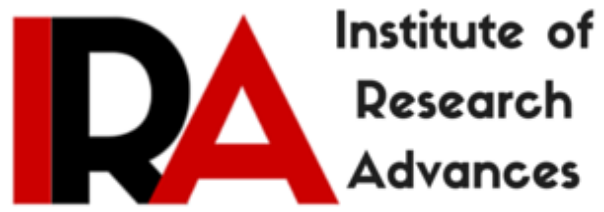

\title{
Aging in India- The Role of State in Health care
}

\section{Dr. Monica Verma}

Assistant Professor, Faculty of Management, Marwadi Education Foundations Group of Institutions

Rajkot, Gujarat, India.

Type of Review: Peer Reviewed.

DOI: http://dx.doi.org/10.21013/jmss.v5.n2.p2

\section{How to cite this paper:}

Verma, M. (2016). Aging in India- The Role of State in Health care. IRA-International Journal of Management \& Social Sciences (ISSN 2455-2267), 5(2), 215-226. doi:http://dx.doi.org/10.21013/jmss.v5.n2.p2

(C) Institute of Research Advances

\section{(cc) EY-NC}

This work is licensed under a Creative Commons Attribution-Non Commercial 4.0 International License subject to proper citation to the publication source of the work.

Disclaimer: The scholarly papers as reviewed and published by the Institute of Research Advances (IRA) are the views and opinions of their respective authors and are not the views or opinions of the IRA. The IRA disclaims of any harm or loss caused due to the published content to any party. 


\begin{abstract}
The world is amidst of an epochal demographic shift that will reshape societies, economies, and markets throughout the next century. The world population, as per United Nations forecasts, will either stabilizel balance or peak around 2050, after growing for centuries at an ever-accelerating rate. The fundamental reason is the decline occurring in birth rates as nations advance economically. As birth rates drop and better health care services delay life traverses ( prolongs life span), the world's population is aging rapidly. However the demographic dynamics in the developing world including India are radically different. Birth rates are still high, and populations are both growing and getting younger. Throughout the following couple of decades, a considerable lot of these nations including India are prone to experience what David Bloom, chair of the department of global health and population at Harvard's School of Public Health, has called a "demographic profit" a rising Proportion of youngsters entering the workforce, driving efficiency and economic development. But our aging population is anticipated to increase fourfold in next decade and this is a growing concern for India. The share of India's population ages 60 and older is anticipated to move from 8 percent in 2010 to 19 percent in 2050, as indicated by the United Nations Population Division (UN 2011. By mid-century, India's 60 and older population is expected to encompass 323 million individuals, a number more noteworthy than the aggregate U.S. populace in 2012. This profound shift in the share of older Indians- occurring with regards to changing family connections and severely limited oldage income support- brings with it an assortment of social, economic, and medicinal services approach challenges.

This paper proposes to contemplate the probable impact of the aging population in India, the challenges to be met and the opportunities to be exploited by investigating demographic, social and economic trends and aspects of aging in India, and advocate the necessity of policy initiatives for the care of older persons in India in terms of their wellbeing needs and budgetary security as it would be obligation of the state to provide, address the need of general population in the nation irrespective of age, standing, caste, sexual orientation and so forth.
\end{abstract}

Key Words : Demographic dividend, aging population, Life Expectancy at Birth, Infant Mortality Rate, Crude Birth/ Death rate.

\title{
Introduction
}

In the most recent century, human civilization has witnessed a silent revolution that has an unpretentious impact significant to practically every one. One of the greatest triumphs of human civilisation is the expanded life span of life ie increase in life expectancy. Indian social order are rapidly changing due to the process of urbanization, higher aspirations among the youth and the increasing participation of women in the workforce. The English speaking and gifted experts from India are emigrating to meet the labour prerequisites of more developed regions. All these factors have prompted the disintegration of the joint family framework and the development of nuclear families. Thus, the elderly individuals are gradually marginalized in their respective families. In addition, the elderly Indians are experiencing a several health care issues and the human services for the matured Indians are not in any manner satisfactory.

All this has Prompted to basically a number of genuine debilitating issues that need to be addressed. The rapid growth of elderly population, steady disintegration of traditional joint family system and inability powerlessness of the administration to maintain the incremental weight of annuity/ pension expenses of its own employees of organised sector leave alone the other from unorganised segment and provisioning of medical services to the old particularly those having a place with rustic zones and beneath the destitution line.

In the future, Bloom (2011a) contends that India's system of family-based backing will not have capacity withstand the increased numbers of older Indians, "especially given increased female work force participation, smaller numbers of more mobile children, augmenting era crevices, and increasing 
burdens of costly-to-treat diseases such as diabetes, cancer, and stroke." Even with the discoveries that adult children still get support from their elderly parents, such social changes would influence the status quo since increases in chronic diseases affect the needs of the elderly and their capacity to continue to work. Alternate factors influence the accessibility of kinfolk to give care. Bloom recommends that India will benefit from gathering high-quality data on population aging and utilizing it to advise on policies to create and expand income support and health insurance programs for older Indians. Likewise, by investing now in the education and training of today's youth, India can lay the basis for increased economic productivity and "facilitate the process of caring for growing numbers of older Indians in the future" (Bloom 2011b).

\section{Literature Review}

Expanding life span and diminishing fertility, has driven the world to the era of the 'ageing population. In the early $20^{\text {th }}$ century, it was expected that populace development would contrarily impact capital aggregation and technological change and because of this, , the problem of a decreasing fertility rate became relevant for many countries, and policies were designed to invert this trend. (Hodgson, 1988). The world population began to decline in the mid-1970s when, in numerous developed nations, the working-age populations (aged between 25-59 years) started to increase faster than the child population (Lee et al., 2011). This imbalance in the population structure has made the alleged 'demographic dividend', deciphered in terms of positive productivity growth in developed countries for few years (Bloom et al., 2001). However, after some time, this unequal age structure has turned into a demographic burden and has made the present ageing issue. The ex post impact of the demographic dividend was the fundamental reason for the aging problem (Hodgson, 988 and Bloom and Williamson, 1998).

The advances in technology and medical science lead to a rising trend in life expectancy for European countries, from 2002 to 2009 (Eurostat,2013). In reality, since 2007, the average life expectancy for countries such as Luxembourg, Spain, Germany, Portugal, Austria, France and Italy was over 80 years of age (Eurostat,2013). Given the present fall in the fertility rate, it is predicted that the prime working age group will be lower than the old age group sooner rather than later, which implies a demographic change with significant influence on the national economies (Mason,2005). Inequality in age structures, particularly on account of a growing old age group, is expected to have multiple effects on the overall economic performance of countries. Several studies (e.g., Bloom et al. 2001; Creedy and Scobie, 2002; Alders and Broer, 2004; Weil, 2006; Sobotka et al., 2010) not just affirm the existence of an ageing population in developed countries, but also identify and analyse the main mechanisms underlying the influence of ageing on economic growth: consumption and saving patterns, public expenditure, and human capital. Regarding the mechanism associated to consumption and savings, (Bakshi and Chen,1994 and Walder and Döring, 2012) contend that the level of disparity regarding the population age structure of a country impacts on the consumption pattern of its households. Because of the ageing problem, the general demand for specific products will be influenced, since they won't give any utility to the older family unit (Walder and Döring, 2012).

The ascent in the ageing population is likewise expected to affect public expenditure and, thus, economic growth. When a country faces an increase in the old age population, public spending on social security expenses and the medical system will be higher than the corresponding spending on education and other forms of development (Eiras and Niepelt, 2012) and Lisenkova et al.,2012). Furthermore, an increase in the old age group will likewise affect a country's sources of income as it will provide less tax revenue. This demographic evolution may also affect Foreign Direct Investment (FDI). Davies and (Robert,2006) show that foreign firms will not invest in a country with an ageing population since the working age population is scarce, therefore negatively affecting the country's capability to produce wealth. Finally, the potential imbalance in the government budget, meaning increasing deficits due to the ageing problem, may also impact on the economy (Tosun, 2003; Lisenkova et al., 2012). 
In most developed countries, government policies and the non-altruistic behaviour of couples have reduced the fertility rate (Alders and Broer, 2004). As a result, their populations are composed of many working age individuals and fewer children to succeed them in the future (Lee et al., 2011). This disproportional age structure leads to scarcity in labour supply and a decline in labour productivity, because the individuals' capacities seem to change along with their age. According to (Mincer,1974), the productive capacity of a society composed of an older labour force will be surprisingly distinctive (lower) from one with a younger labour force. (Hock and Weil 2012) argue that a rise in the ageing population will increase the burden on the working age group as they have to expend a larger share of their income on the elderly. A rise in the ageing population tends to abatement government revenue through labour income tax and increase government spending through pension and health care expenditures (Tosun 2003; Blake and Mayhew, 2006) view that the rise in government spending due to an ageing population bares no effect on economic growth as long as there is a continuous rise in immigration

\section{Demographic Trends}

The Indian population has expanded from 361 million in 1951 to 1.21 billion in 2011.. Simultaneously, the number of older people has increased from 19 million (4 percent of total population) to 103.84 million (8.6 percent of the total) during the same time span (Registrar General of India). Keeping in mind the end goal to contemplate the ramifications of an aging population in India, the changing Indian demographic arrangement should be highlighted first. That will help us evaluate the difficulties to be met later on. The notable elements, representing the past trends of the Indian population, are given in the accompanying table:

\begin{tabular}{|c|c|c|c|c|}
\hline Year & 2011 & 2001 & 1991 & 1981 \\
\hline Population Size (in million) & 1210 & 1027 & 846.30 & 683.33 \\
\hline Decadal Growth Rate (in \%) & 17.7 & 21.35 & 23.67 & 24.66 \\
\hline Older Population (in millions) & 103.84 & 77 & 57 & 43 \\
\hline Percentage of older Persons & 8.6 & 7.5 & 6.7 & 6.5 \\
\hline Life Expectancy at Birth (Years) & $68(2011-15)$ & $\begin{array}{l}\text { 65.34( 2001- } \\
06)\end{array}$ & 59.40 & 55.5 \\
\hline Infant Mortality Rate per 1000 & $38(2011-15)$ & $56(2008)$ & 80 & 110 \\
\hline Crude Birth rate per 1000 & $20(2011-15)$ & $18.0(2008)$ & 29.5 & - \\
\hline Crude Death rate per 1000 & $7(2011-15)$ & $7(2006-10)$ & 9.8 & - \\
\hline Literacy Rate(percentage) & 74.04 & 64.84 & 52.20 & 43.57 \\
\hline $\begin{array}{l}\text { Percentage of children of age } 0-6 \\
\text { years } \\
\text { in the total population }\end{array}$ & 13.12 & 15.37 & 17.94 & - \\
\hline Density (population per sq. km.) & 382 & 324 & 267 & 216 \\
\hline
\end{tabular}

Source: Census of India,2011, 2001, 1991 and 1981.

From the above table, it may be noted that the size of the population is increasing, in spite of the fact that the decadal growth rate is decreasing. Simultaneously, the number of senior citizens, as well as their proportion, is gradually increasing. The average life expectancy at birth has become reasonably longer, while infant mortality rate and crude death rate as well as crude birth rate have reduced remarkably. The higher literacy rate represents an incremental spread of education, leading to a better level of awareness. The reduced infant mortality rate signifies the improvement in mother-child care as well as the healthcare facilities during the above period. It also motivates couples to choose to have fewer children due to a higher certainty of their survival, and hence the increased likeliness that they will be a source of support to the parents during old age. A reduction in crude birth rate reduces the supply of younger people, while a decreasing death rate signifies the increasing number of older 
people with a longer life expectancy. However, the presence of 13.12 percent children, although reduced from 15.37 percent in 2001, has made India the youngest nation in the world.

\section{Future Projections}

The size and the structure of the Indian population, as projected by the Population Division, Department of Economic and Social Affairs, United Nations Secretariat, is given in the accompanying table:

TABLE 2 Projected Changes in Indian Demography (in millions)

\begin{tabular}{|l|l|l|l|l|l|l|l|}
\hline $\begin{array}{l}\text { Age } \\
\text { Group }\end{array}$ & $\mathbf{2 0 0 0}$ & $\mathbf{2 0 1 5}$ & $\mathbf{2 0 2 5}$ & $\mathbf{2 0 3 0}$ & $\mathbf{2 0 3 5}$ & $\mathbf{2 0 4 0}$ & $\mathbf{2 0 5 0}$ \\
\hline $\begin{array}{l}0-14 \\
\text { years }\end{array}$ & $\begin{array}{l}347 \\
(34.14)\end{array}$ & $\begin{array}{l}345 \\
(27.68)\end{array}$ & $\begin{array}{l}337 \\
(24.63)\end{array}$ & $\begin{array}{l}327 \\
(23.08)\end{array}$ & $\begin{array}{l}313 \\
(21.53)\end{array}$ & $\begin{array}{l}300 \\
(20.20)\end{array}$ & $\begin{array}{l}285 \\
(18.60)\end{array}$ \\
\hline $\begin{array}{l}15-59 \\
\text { years }\end{array}$ & $\begin{array}{l}593 \\
(58.31)\end{array}$ & $\begin{array}{l}782 \\
(62.76)\end{array}$ & $\begin{array}{l}865 \\
(63.15)\end{array}$ & $\begin{array}{l}895 \\
(63.16)\end{array}$ & $\begin{array}{l}919 \\
(63.17)\end{array}$ & $\begin{array}{l}937 \\
(63.10)\end{array}$ & $\begin{array}{l}938 \\
(61.26)\end{array}$ \\
\hline$\geq 60$ years & $\begin{array}{l}77 \\
(7.55)\end{array}$ & $\begin{array}{l}119 \\
(9.56)\end{array}$ & $\begin{array}{l}167 \\
(12.22)\end{array}$ & $\begin{array}{l}195 \\
(13.76)\end{array}$ & $\begin{array}{l}223 \\
(15.30)\end{array}$ & $\begin{array}{l}248 \\
(16.70)\end{array}$ & $\begin{array}{l}308 \\
(20.14)\end{array}$ \\
\hline Total & 1,017 & 1,246 & 1,369 & 1,417 & 1,455 & 1,485 & 1,531 \\
\hline
\end{tabular}

Source: Population Division, Department of Economic and Social Affairs, United Nations Secretariat, World Population Prospects: The 2002 Revision and World Urbanization Prospects: The 2001 Revision, http://esa.un.org/unpp. (Figures in parentheses show the percentage of total population.)

From the above projections, we observe that during the next five decades the size of the population will grow by about 50 percent, but the number of older people will increase fourfold. The proportion of older people in the population will grow at a higher pace than the other groups. Thus there is need for the policymakers in India to take a critical note regarding observation of a receding trend of the younger people, and increasing trend in older persons. The pattern is prone to have unfavourable effect on the supply of adolescents in the occupation market, cause strain on the assets/ resources because of more latent individuals and necessity for redistribution/engagement of state assets towards meeting the wellbeing needs and security of aged persons. The information in the above table is further broke down and the key parameters identified with the maturing populace are in the table underneath:-

TABLE 3 Projected Key Parameters: Aging Population of India

\begin{tabular}{|l|l|l|l|l|l|l|l|}
\hline \multicolumn{1}{|c|}{ Year } & $\mathbf{2 0 0 0}$ & $\mathbf{2 0 1 5}$ & $\mathbf{2 0 2 5}$ & $\mathbf{2 0 3 0}$ & $\mathbf{2 0 3 5}$ & $\mathbf{2 0 4 0}$ & $\mathbf{2 0 5 0}$ \\
\hline $\begin{array}{l}\text { Median Age } \\
\text { (years) }\end{array}$ & 23.4 & 27.2 & 30.3 & 31.4 & 33.5 & 35.0 & 37.9 \\
\hline $\begin{array}{l}\text { Dependency } \\
\text { Ratio-Total }\end{array}$ & 71.5 & 59.3 & 58.3 & 58.3 & 58.3 & 58.5 & 63.2 \\
\hline
\end{tabular}




\begin{tabular}{|l|l|l|l|l|l|l|l|}
\hline $\begin{array}{l}\text { Dependency } \\
\text { Ratio- } \\
\text { Young }\end{array}$ & 58.5 & 44.1 & 39.0 & 36.5 & 34.1 & 32.0 & 30.4 \\
\hline $\begin{array}{l}\text { Dependency } \\
\text { Ratio-Old }\end{array}$ & 13.0 & 15.2 & 19.3 & 21.8 & 24.2 & 26.5 & 32.8 \\
\hline $\begin{array}{l}\text { Index of } \\
\text { Aging } \\
\text { (percent) }\end{array}$ & 22.2 & 34.5 & 49.6 & 65.0 & 71.2 & 82.7 & 108.1 \\
\hline
\end{tabular}

Source: Computed from the Table 2

From the Table 3 above it is evident that the Indian demography will gradually swinging to a greyer within next few decades. The median age of the population is likely to increase gradually from 23.4 years in 2000 to 30.3 years in 2025 and, finally, to 37.9 years in 2050 . During the period, the old age dependency ratio is likely to go up from 13.0 percent in 2000 to 32.8 percent in 2050 , while the young dependency ratio is expected to come down from 58.5 percent to 30.4 percent during the period. The index of aging (aged-child ratio) will increase from 22.1 percent to 108.1 percent meaning atleast every three working Indians will have to take care of one elderly person by 2050 as compared to about eight working Indians at present. The reason for such a demographic transition may be attributed to progression over the time in therapeutic science, better nourishment, increased order of awareness among the general masses, successful implementation of the public health policies vis-à-vis social and economic developments (WHO 1999).

Overall it is estimated that an Indian of age 60 years today is expected to survive another 15 years. Similar projections have also been made by the Office of Registrar General India. Accordingly the the number of inhabitants in 60 or more in 2026 is estimated to reach 173 million, which would constitute more than 12 percent of the total population. The UN defines a country as 'ageing' where the proportion of people over 60 reaches seven per cent. India has as of now surpassed this and is likely to reach 12.6 per cent by 2025 . The old dependency ratio, which is the number of people aged 60 and above per 100 persons in the working ages (15-59), will be 19 percent in 2026, resulting in increase in median age from 22.5 years to 31.4 years between 2001 and 2026 (Office of Registrar General India, 2006).

India as of now positions fourth among the nations of the world with a substantial elderly population preceded by China in the neighbour. The decline in mortality and fertility is likely to accentuate the process of population aging further in the country. It is also estimated that $80 \%$ of the elderly Population in India will be in the rural areas out of which $50 \%$ will be women and $30 \%$ of the total elderly will be below the poverty line.

\section{Socio psycho Implications}

Demographic transition is also accompanied by changes in society and economy. Beyond the statistics, there are several socio psycho implications that the geriatric segment is likely to go through and that need to be considered for State intervention.

\section{a. Social Trends:}

The rural India since the beginning, was mostly an agro -economy. The economic environment led to the formation of joint families the institution of family provided the necessary social and financial support during the various stages of life. The elderly played a significant role in decision making regarding household matters, while the younger people were usually entrusted with the responsibility of ensuring their well-being. Elderly thus commanded care in traditional Indian society. 


\section{b. Urbanisation}

On the other hand, the growth of rural population has decreased the area of arable land and is unable to meet the increased demand for housing, employment etc thereby leading to incremental and disguised unemployment. As a result, the rural masses migrate to the urban areas in search of a livelihood. The migrants, mostly the youth, relocate for better earning opportunities, leaving their elderly parents in the villages. Moreover, the higher cost of living in urban areas and the lack of space for all members of a family to reside at the same place are causing the disintegration of the joint family system. This urbanization and industrialization has disturbed the extended and joint family setup further. Thus the crumbling of joint family system have conspired to increase insecurity and loneliness among the geriatric population.

\section{c. Migration}

The population in India is aging in line with the world population and the population of the less developed regions. But the age distribution structure of the Indian population is moving from a pyramid-shaped structure to a hexagonal one, whereas in developed countries the same is transforming to an inverted pyramid. As such it is likely that the developed nation may face shortage of manpower, labour resources to sustain their economic development that inter-alia as per the trend today may lead to increased migration of urban youth to these countries for employment. This in turn may result in increasing the number of lonely older persons back in India who may need the financial support but would require a geriatric health care.

\section{d . Changing Women Employment scenario}

Traditionally in the Indian society women assume an imperative role of caregivers, especially to the aged and children. But with the increasing trend in the women education the employment rate of women is also increasing. The female workforce has increased in organised sector over the years and this in turn is affecting the care giving role of women at home of old and children. Like children, old people unquestionably deserve more care and emotional support at the concluding chapters of their life. But such expectations can only be met with heavy implications for individuals as well as for society. Hence, it may be a challenge for the society to work out a long term sustainable solution. In the Indian context, concepts of old age homes and Third Party Geriatric Care are yet to mature. Existing social framework looks down at the recommendation of sending maturing guardians/relatives to "Homes."

\section{Health of Elderly}

According to the study directed by ICMR, AIIMS, the elderly individuals in India experience the ill effects of double medicinal issues, i.e., both transmittable and in addition non-communicable ailments. This is further aggravated by hindrance of uncommon tactile capacities like vision and hearing. A decline in immunity as well as age-related physiologic changes leads to an increased burden of communicable diseases in the elderly. The prevalence of tuberculosis is higher among the elderly than younger individuals. The most prevalent morbidity was anemia, followed by dental problems, hypertension, chronic obstructive airway disease (COAD), cataract, and osteoarthritis. Elderly individuals are exceedingly prone to mental morbidities due to ageing of the brain, problems associated with physical health, cerebral pathology, socio-economic factors such as breakdown of the family support systems, and decrease in economic independence. The mental disorders that are every now and again experienced incorporate dementia and temperament issue. The mental disorders that are frequently encountered include dementia and mood disorders. Other disorders include neurotic and personality disorders, drug and alcohol abuse, delirium, and mental psychosis.

In brief the problem of the elderly is multi dimensional - viz. physical, social and psychological which have been accelerated by spread of modernization, growing urbanization, the breakdown of the joint family system and ascent of nuclear families. The issue further gets exasperated with both life partners working leaving very little time for parents. However, the increasing pace of life among the 
younger generation has resulted in a widening gap between them and their seniors. Economic nonproductivity, guilt of being dependent, absence of family bolster, failing physical abilities and mental disorders are some of the nagging problems of elderly population in India.

Adding up all the socio-economic factors, it becomes evident that this 10 per cent segment of ageing citizens requires equal or if not more attention than the new born and infants at the other end of the social spectrum. Needless to say, a significant part of such an intervention has to happen from public spending.

Although at present most in the country including the Policy makers are not more concerned of aging considering it simply a number that is rising. The attention is generally on the youthful population who are thought to be the asset of the nation as they are prone to add to the Gross domestic product. But in order to reap the demographic dividend it is imperative that the issues pertaining to the old persons also be addressed. The present issue of old is like the one like of environment. Few years ago it was talked that the environment an issue that needs to be addressed but initially the problem was left unaddressed and now the situation is so dismal.

But it would be prudent that the mistake is not rehashed again in the case of aging problem and the issue need to be addressed in time before the problem becomes a perennial crisis as in developed countries.

At present numerous times aging is ignored thinking of it as is an issue of created nation and not of India. The year 2025 is far away and as the present political and administrative actors are not likely to be there at that time it is not on their priority agenda. It may be mentioned that like India, the present developed countries who are going through the problem of greying population today have once enjoyed the demographic dividend.

Accordingly in India the problem may not be considered requiring immediate emergency measures/ interventions, it may be contended that there ought to be prepared readiness to handle the issue once it happens in fragile living creature and blood. It is likewise essential as the early measure would help in reaping the benefits of demographic dividend more.

\section{State Intervention}

Well-being of older persons has been mandated in the Constitution of India. Article 41, a Directive Principle of State Policy, has directed that the State shall, within the limits of its economic capacity and development, make effective provision for securing the right of public assistance in cases of old age. There are other provisions, too, which direct the State to improve the quality of life of its citizens. Right to equality has been guaranteed by the Constitution as a Fundamental Right. These provisions apply equally to older persons. Social security has been made the concurrent responsibility of the Central and State Governments.

The total expenditure on health as percentage of GDP for 1996-2000, 2001-05, 2006-10 and 2011-15 has been 4.3, 4.4, 4.5 and 4.7 respectively. Over the same period public expenditure as percentage of GDP has been 1.2, 1.2, 1.3 and 1.4 respectively (World Bank)

The Government of India adopted a National Policy on older Persons in 1999 that envisions to augment support for financial security, health care, shelter, welfare and other needs of older persons, provide protection against abuse and exploitation, make available opportunities for development of the potential of older persons, seek their participation, and provide services so that they can enhance the quality of their lives.

Indira Gandhi National Old Age Pension Scheme" (IGNOAPS) initiated under the policy is available accessible to every destitute individual aged 65 years or older. This scheme is executed in the State and Union Territories through Panchayats and Municipalities. Both Panchayats and 
Municipalities are encouraged to involve voluntary agencies as much as possible in benefiting the destitute elderly for whom this scheme is intended.

Under the IGNOAPS, the Central Government accommodates for Rs. 200/- per pensioner per month in the age group of 60-79 years and Rs. 500/- per month to person of 80 year and above and belonging to below poverty line (BPL) household and the states are urged to contribute an equal amount. The scheme is implemented as per state guidelines and the old age pension beneficiaries should be given the benefit regularly each month before $7^{\text {th }}$ of the month. However, the benefits of the program are questionable in terms of the meagre budget, improper identification of beneficiaries, lengthy procedures, and irregular payment.

National Programme for Health Care for the Elderly (NPHCE) : The MoHFW launched the NPHCE during the year 2010-11, in the $11^{\text {th }}$ plan period. It's an articulation of the International and national commitments of the Government as envisaged under the UN Convention on the Rights of Persons with Disabilities (UNCRPD), National Policy on Older Persons (NPOP) adopted by the Government of India in 1999 and Section 20 of "The Maintenance and Welfare of Parents and Senior Citizens Act, 2007" dealing with provisions for medical care of Senior Citizen. The Centre will bear $75 \%$ of the total budget and the State Government will contribute $25 \%$ of the budget, for activities up to district level

The programme has envisaged to provide promotional, preventive, curative and rehabilitative services in an integrated manner for the Elderly in various Government health facilities. The range of services will include health promotion, preventive services, diagnosis and management of geriatric medical problems (out and in-patient), day care services, rehabilitative services and home based care as needed. Districts will be linked to Regional Geriatric Centers for providing tertiary level care. Main objective of the programme is to provide preventive, curative and rehabilitative services to the elderly persons at various level of health care delivery system of the country and to strengthen referral system, to develop specialized man power and to promote research in the field of diseases related to old age.

National Rural Health Mission (NRHM). NRHM is a comprehensive programme that seeks to improve rural health through decentralized planning and interventions. The main aim of NRHM is to provide accessible, affordable, accountable, effective and reliable primary health care facilities, especially, to the poor and vulnerable sections of the population. NRHM seeks to strengthen Public Health delivery services at all levels. The interventions/initiatives launched under the NRHM aim to reduce mortality and morbidity, and consequently improve life expectancy. However though the programme addresses the need for but lacks focus for the geriatric care.

There is need to address the geriatric health care services through NRHM as the predominantly the elderly reside in rural India. There is need for several interventions, a few enumerated below:

- The lack of trained doctors/personnel in geriatric care is the biggest impediment. At present there are a couple of universities (Chennai and IGNOU) which offer specialized post graduate courses in geriatric care. This requires active government intervention in expanding the number of seats in medical colleges across the country

- The geriatric health care should be strengthened at the Primary Health Care level so that the problems of day to day well being of $75 \%$ of the old population can be taken care of. The specialised training programmes for Medical officer in geriatric medicine at primary health care may be provisioned. The peripheral health workers and community health volunteers should also be trained in the geriatric medicine to identify and refer elderly patients for timely and proper treatment. 
- At presently the care of geriatric population is at best a charitable exercise largely dependent on Non Governmental Organisations and socio-religious organizations. The participation of such self motivated groups is welcome but to increase the participation of other needs a viable business model.

For example the NGOs/Companies venturing out into geriatric health care need to be assisted by the govt in acquisition of land on long term leases or outright purchase by the state governments, must have accessibility to cheaper institutional credit. Wherever institution have come up providing exclusive health care to geriatric population in terms of day care / residential facilities or through mobile clinics or by provisions of attendants at home etc , there income needs to exempted from taxes for a particular period till they are able to recoup their actual investments. Institution involved in geriatric health care research /training can be given deduction under section 35 of the IT Act.

- Since $90 \%$ of the geriatric population is from the unorganized sector with a predominat rural base, it is essential that the identification of the aged must be done by the community institutions i.e the panchayats. These identified cases must be abetted by the district administration and may be issued a cards like a smart card for health care that can be used at each level of healthcare facility and also can be used while utilizing the services of any institution both health as well as the pension.

- Institution which are serving the geriatric population as part of a multi specialty centre, then the cost incurred on providing the services to this age group can be claimed as deduction either in entirety or as a certain portion. The expenditure can be tracked by the smart card issued to the target population.

- The geriatric population can be covered by insurance and the concept of couple needs to be insisted upon so that women are not left out.

National Urban Health Mission (NUHM) The Union Cabinet vide its decision dated 1st May 2013, has approved the launch of National Urban Health Mission (NUHM) as a Sub-mission of an overarching National Health Mission (NHM). NUHM envisages to meet health care needs of the urban population with the focus on urban poor, by making available to them essential primary health care services and reducing their out of pocket expenses for treatment

\section{Conclusion}

Improvement in health care infrastructure and facilities and ease of access to them is the only way India can fight against diseases. The Government has attempted to give a boost to public health care by raising public health spending through a large program called the National Rural Health Mission (NRHM). However, the state of affairs, as they are now, is not very encouraging. The average growth in expenditure on total healthcare is not only lower than the average GDP growth rate, the expenditure is still lower (as a \% of GDP) than the expenditure of even low-income countries, as classified by the World Bank. In fact, the growth in expenditure on total healthcare in India has been decreased from what it was a decade ago (from 4.3 per cent to 4.05 per cent).

But health care reforms should not just increase funding but also address inequality of access and include regulations to limit cost inflation. Money alone, channelled through insurance and infrastructure strengthening, is inadequate to address the current problems of unaffordable health care and the future challenges posed by aging populations that are increasingly affected by noncommunicable diseases. Paradoxically, initiatives to increase the well-being of older Indians may lead to higher poverty rates, if impoverished Indians remain poor but begin living to older ages rather than dying young as many now do Evaluating these programs solely on the basis of changes in poverty rates among the elderly would not adequately capture the benefits to society. 


\section{References}

- Annual Report of Ministry of Health and family welfare

- Annual Report of Ministry of Social Justice and Empowerment

- Alders, P. and Broer, P.D. (2004), "Ageing, fertility, and growth", Journal of Public Economics,

- Bakshi, G. S. and Chen, Z. (1994), "Baby boom, population aging and capital markets", Journal of Business, 67:165-202.

- Bloom, D.E., Canning, D., and Sevilla, J. (2001), The Demographic Dividend. A New perspective on the Economic Consequences of Population Change, A RAND program of Policy- Relevant Research Communication.

- Bloom, D.E. and Williamson, J. G. (1998), "Demographic transition and economic miracles in emerging Asia", The World Bank Economic Review, 3: 419 -455.

- Bloom, D. E., Börsch-Supan A., McGee, P. and Seike, A. (2011), "Population aging: facts, challenges, and responses", PGDA Working Paper No. 71

- Blake, D. and Mayhew, L. (2006), "System in the light of population ageing and declining fertility", The Economic Journal, 116: 286 - 305.

- Creedy, J. and Scobie, M.G. (2002), "Population ageing and social expenditure in New Zealand: stochastic projections", New Zealand Treasury Working Paper 02/28. 89: 10751095.

- Census publication, Office of Registrar General

- Davies, B. R. and Robert III, R.R. (2006), "Population aging, foreign direct investment, and tax competition", SAID Business School, 1HPWP 07/10.

- Eurostat (2013), "Life expectancy by age and sex", in http://epp.eurostat.ec.europa.eu/

- $\quad$ portal/page/ portal/population/data/database, accessed on 25th March 2013.

- Eiras, M. G. and Niepelt, D. (2012), "Ageing, government budgets, retirement and growth", European Economic Review, 56: 97 -115.

- Hodgson, D. (1988), "Orthodoxy and revisionism in American demography", Population and Development Review, 4: 541 - 569.

- Hock, H. and Weil, N.D. (2012) "On the dynamics of the age structure, dependency and consumption”, Journal of Population Economics, 25: 1019-1043.

- Lisenkova, K., Mérette, M. and Wright, R. (2012), "The Impact of population ageing on the labour market: evidence from overlapping generations computable general equilibrium (OLG-CGE) model of Scotland", Discussion paper in Economic, Strathclyde, 12-13.

- Lee, H. S., Mason, A. and Park, D. (2011), "Why does population aging matter so much for Asia? Population aging, economic security and economic growth in Asia”, ERIA Discussion Paper Series, ERIA-DP-2011-04.

- Mason, A. (2005), Demographic Transition and Demographic Dividends in Developed and Developing countries, United Nations Expert Group Meeting on Social and Economic Implications of Changing Population Age Structure, UN/POP/PD/2005/2. 
- Mincer, J. (ed.) (1974), Age and Experience Profiles of earnings, New York: Columbia University Press.

- Publication on Population, united nations

- Sobotka, T., Skirbekk, V. and Philipov, D. (2010), Economic Recession and Fertility in the Developed World Literature Review, European Commission, Directorate-General Employment, Social Affairs and Equal Opportunities Unit E1 - Social and Demographic Analysis.

- Tosun, S. M. (2003), "Population aging and economic growth political economy and open economy effects", Economics Letters, 81: 291-296.

- Weil, N. D. (2006), "Population Aging”, NBER Working Paper No. 12147

- Walder, B. A. and Döring, T. (2012), " The effect of population ageing on private consumption - a simulation for Austria based on household data up to 2050", Eurasian Economic Review, 2: $63-80$

- $\quad$ http://data.worldbank.org/indicator/SP.DYN.CDRT.IN

- http://www.prb.org/Publications/Reports/2012/india-older-population.aspx 